\title{
Digital transformation of management resources for a comfortable tax environment
}

\author{
Valeriy Ivanovich Bratcev and Anastasiya Mikhailovna Simachkova ${ }^{1}$ \\ Plekhanov Russian University of Economics, Department for Accounting and Taxation, Moscow, \\ Russia
}

\begin{abstract}
With the use of digital technologies, a person's daily life, industrial relations, economic processes and education are changing, as well as new requirements for communications, computing power, information systems and services arise. The article reflects the main results of the digital transformation of tax authorities, contributing to the creation of a comfortable tax environment in the context of the general digitalization of the economy. The study aims to determine the causal relationship between the management decisions made by the tax authorities and the dynamics of obligatory payments to the budgets of the budgetary system of the Russian Federation, as well as to formulate proposals for improving the advanced developments of tax authorities aimed at creating a comfortable tax environment, reflecting the principles of the "economy of trust". The solution of the tasks set in the work was carried out on the basis of the application of general scientific research methods within the framework of comparative, logical and statistical analysis, etc. Among key findings of the research, we should mention the substantiation of the transformation of the management resources of the tax authorities under the influence of the development of digital technologies, as well as the development of practical recommendations for improving the advanced developments of the tax authorities (tax monitoring system, special tax regime for self-employed citizens, single tax payment system) in the framework of creating a comfortable tax environment and building trusting relationships with taxpayers.
\end{abstract}

Keywords: digital transformation, tax authorities, tax administration, economy of trust

\section{Introduction}

Digital transformation affects all social and economic spheres, including posing new challenges for the tax authorities: the need to introduce advanced information technologies in a short time, the importance of qualitative changes in the organizational structure and human resources, the imperfection of the current legislation in the context of the accelerated pace of digitalization development, etc. In addition, along with the development

\footnotetext{
${ }^{1}$ Corresponding author: anastasiva.simachkova@inbox.ru
} 
of information technologies, the needs of taxpayers to receive services provided by the Federal Tax Service of Russia in a fast, affordable and high-quality way are growing [1].

In such conditions, like business, tax authorities need to use new modern approaches to data flow analytics, as well as maintain constant communication with taxpayers in order to implement high-quality tax administration and create a comfortable tax environment [2].

In modern scientific works, the digital transformation of tax authorities is often reduced exclusively to the service component:

- fast and contactless work with conscientious taxpayers is considered as a priority area of work of tax authorities [3];

- among the indicators of "digital maturity" of tax authorities, the key role is assigned to the development of multitasking services for electronic interaction with taxpayers [4];

- the development of electronic services is highlighted as a determining factor affecting the rate of tax authorities [5].

At the same time, this is not enough for creating a comfortable tax environment. An integrated approach is needed when considering the impact of digitalization of the economy on the transformation of the management resources of tax authorities [6]. The digital transformation of tax authorities is not only the development and implementation of new technologies, but also organizational changes, the emergence of new competencies, infrastructure renewal, etc. [7].

So, nowadays, the Federal Tax Service of Russia has increased administrative capabilities through the digitalization of its activities:

- the quality of tax control is increasing, including through the introduction of modern software products that allow taking into account new tax risks arising from the general digitalization of the economy (ASK "NDS-2", AIS "Tax-3", good traceability system, online checkout system, etc.);

- the efficiency of interaction with taxpayers is increasing, including due to the introduction of digital (electronic) services (today, more than 60 different electronic services are presented on the official website of the Federal Tax Service of Russia), as well as a qualitative change in the approach to interaction with taxpayers (special attention is paid to feedback);

- $\quad$ human resources are being strengthened by improving recruitment opportunities based on remote technologies (personnel projects of the Federal Tax Service of Russia "Make a career yourself!", "PROmotion", etc.), which contributes to the creation of effective project teams capable of proposing new ideas aimed at modernizing tax authorities and improving tax administration;

- the quality of tax administration is improved through the use of a scientifically grounded system of employee motivation.

\section{$2 \quad$ Materials and Methods}

\subsection{Descriptive Design}

The digital transformation of the activities of tax authorities has made it possible to fundamentally change the approach to tax administration of certain categories of taxpayers, creating a comfortable and not burdensome administrative environment for both taxpayers and tax authorities [8]. The introduction of a tax monitoring system and a new special tax 
regime for self-employed citizens (tax on professional income) is the most striking example of such a transformation.

The tax monitoring system in 2020 at the OECD International Forum on Tax Administration was named the best practice for building effective digital interaction between the state and taxpayers. It replaces traditional forms of tax control with online interaction based on remote access of tax authorities to the accounting and tax reporting of taxpayers. At the end of 2020, tax monitoring covered 30\% of tax revenues [9].

A special tax regime for the self-employed was also named among the world's best practices. It is based on contactless and non-declaration taxation due to technical solutions built into the information system "My Tax".

It should be mentioned that the number of taxpayers wishing to become participants is growing on an ongoing basis, including due to transparency, convenience and ease of interaction with tax authorities.

For example, over the five years of tax monitoring, the number of participants has increased 30 times. In 2021, 209 taxpayers representing 15 industries (114 new and 95 existing members) participate in tax monitoring. Today, about $93 \%$ of participants provide remote access to accounting information or to the corresponding data marts, which allows tax authorities to fully use the capabilities of remote control, significantly reducing the volume of document reclamation [10].

In addition, the development of digital technologies has made it possible to expand the list of potential participants in tax monitoring by changing the relevant criteria.

As for the special tax regime for the self-employed, in general, since the beginning of 2019, the number of participants has increased to 2 million. It should be mentioned that, in accordance with the explanations of the Ministry of Finance of the Russian Federation, it is possible to register as a self-employed person from the age of 14. As of 23.03.2021, 25 thousand minors $(1.3 \%)$ were registered as self-employed.

During the period of the said tax regime, the self-employed registered 327 billion rubles in income, which led to the payment of tax in the amount of 8 billion rubles. At the same time, $85 \%$ of registered taxpayers had not previously declared income from business activities, and $40 \%$ had no official income at all in the year before registration [11].

\subsection{Exploratory Design}

Another striking example of creating a comfortable tax environment in the context of digital transformation is providing taxpayers with the opportunity to use the mechanism of a single tax payment (STP). It allows you to transfer obligatory payments in one payment order without specifying the type of payment, the term for its payment, belonging to the budget, which significantly reduces the risk of making a mistake, as well as the formation of debt. The tax authority independently, on the basis of available information, set off the transferred funds against the obligations of the payer.

The STP mechanism for citizens was introduced in 2019 to pay property taxes, and from 2020 the ability to pay personal income tax was added in this way. The number of individuals using this mechanism is gradually growing: in less than 10 months of 2020, over 110 thousand citizens took advantage of the possibilities of a single tax payment, transferring 2.7 billion rubles. This is more than five times the corresponding figure for the whole of 2019 [12].

Today, it is planned to extend the possibility of using the STP also to individual entrepreneurs and legal entities. It is expected that the State Duma of the Federal Assembly of the Russian Federation will consider draft law No 1141868-7 in the second reading. If the 
relevant draft law is adopted, organizations and individual entrepreneurs will be able to pay all obligatory payments also with one payment order. First, the amount of the STP will be used to pay off the existing debt, then on the account of forthcoming payments with the earliest due date, and in their absence - on account of the debt for payment of penalties, interest and fines.

The adoption of such changes will significantly reduce the time for processing, settlement documents, and will also prevent taxpayers from creating tax debt.

At the same time, it is rather difficult to motivate the commercial sector to use STP, given the peculiarities of this system. It is highly undesirable for a business to withdraw funds for the purpose of early fulfillment of tax obligations, since these funds could be used, for example, to expand production or invest, which could potentially lead to an increase in profits. In this case, for business, STP is a kind of budget advance. In addition, the STP must be paid on the first of all available due dates for the payment of taxes and insurance contributions, which occur during the entire reporting period.

\section{$3 \quad$ Results}

The use of modern digital technologies allows tax authorities to significantly simplify and make transparent interaction with taxpayers [13]. Technologies of "contactless" work with taxpayers in real time are the foundation of the tax administration of the future.

Digital transformation efforts are delivering strong results. According to the Federal Tax Service of Russia, the consolidated budget of the Russian Federation in 2020 received $21,013.9$ billion rubles $(8.2 \%$ less than in 2019 , which is due to restrictions caused by the COVID-19 pandemic), in 2019 received $22,737.1$ billion rubles (6.6\% more than in 2018) and in 201821328.5 billion rubles were received (23.0\% more than in 2017). A similar dynamics is observed in relation to revenues to the federal budget and to the consolidated budgets of the constituent entities of the Russian Federation. Structure of revenues to the consolidated budget of the Russian Federation in 2018-2020 is presented in Fig. 1.

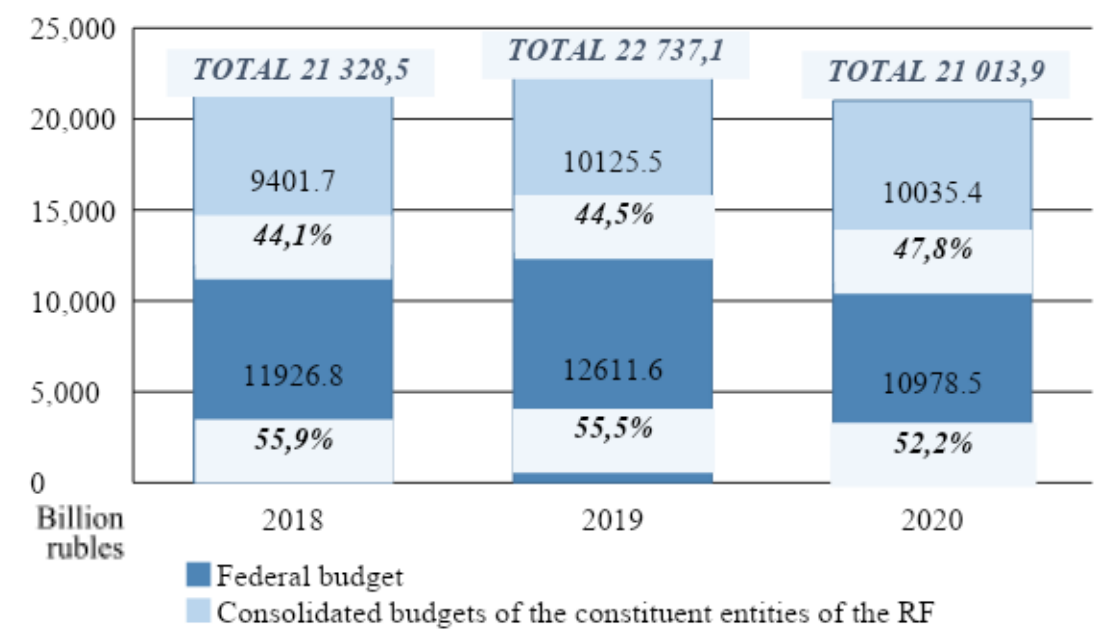

Fig. 1. Analysis of revenues to the consolidated budget of the Russian Federation in 2018-2020. Source: Compiled by the authors based on statistics from the Federal Tax Service of Russia [14]. 
These results were achieved precisely due to the synergistic effect from the introduction of modern digital technologies in tax authorities and, as a result, the digital transformation of the management resources of the Federal Tax Service of Russia.

The introduction of innovative technologies into the work allowed the tax authorities to conceptually change the paradigm of control work, systematically reduce the administrative burden on taxpayers and increase the efficiency of interaction with them as part of the formation of a comfortable tax environment based on the principles of customer-centricity in the context of the digitalization of the economy [15].

The transition to working with big data, attention to the interaction with taxpayers, increased transparency of activities allowed the tax authorities of the Russian Federation to become like the leading digital platforms.

\section{Discussion}

At the same time, it should be mentioned that, according to a number of experts, digitalization of tax administration not only contributes to the creation of a comfortable tax environment, but also becomes one of the factors of tax risk for entrepreneurs [16]. For example, one of the key tasks of tax authorities in the framework of digital transformation is to ensure reliable information protection and security of tax administration systems [17].

Moreover, even the advanced developments of the tax authorities need to be refined, both from the technical side and from the side of legal regulation. For example, the considered achievements of digital transformation of tax authorities today have a number of significant disadvantages that affect the use of these systems by taxpayers.

1. Small business cannot become a member of tax monitoring (as of June 10, 2021, the number of small and micro enterprises exceeds the number of medium-sized enterprises by 5,836 thousand units, or more than 330 times) [18]. Of course, the connection to the tax monitoring system for this category of taxpayers due to the significant cost of the required software is quite problematic. At the same time, the creation by the tax authorities of a mechanism for obtaining a motivated opinion about the specific life situation of the taxpayer (for example, about the completion of a specific transaction) based on the analysis of the submitted materials (documents, information) using modern digital technologies, including artificial intelligence technologies, will allow taxpayers to avoid errors in the calculation of obligatory payments, will increase their financial literacy, and will also allow the tax authorities to analyze the issues that pose the greatest difficulties for taxpayers and opportunely respond to the corresponding challenges.

2. According to a study of the Higher School of Economics (NRU HSE), there are 8 million self-employed citizens in Russia in 2021, or about $11 \%$ of the total employed population (the average estimate of Rosstat, NRU HSE, World Bank, OECD and Russian Presidential Academy of National Economy and Public Administration is 7.2 million self-employed) [19]. At the same time, as noted earlier, in 2021 the number of registered self-employed is only about 2 million people. Thus, today the tax authorities need to take additional measures to stimulate the registration of citizens as self-employed, including taking into account the possibilities of modern digital technologies. For example, one of the most effective ways is the integration of the information system "My Tax" with digital platforms that unite service providers and their clients (Profi.ru, "Yandex.Services", etc.).

3. Partial refund of funds transferred as a STP is not provided. Only the remainder after the STP is set off towards the payment of obligatory payments after the expiration of the payment due date is subject to return. The introduction of such a mechanism will allow the business, if necessary, to return a part of the funds transferred as the STP. Due to modern 
digital technologies, it will be possible to set a limit for such a partial refund (for example, no more than the amount of the next obligatory payment). Thus, the use of the STP system will not be as burdensome for the commercial sector, which will lead to an increase in the use of such a mechanism, which in turn can potentially affect the reduction of tax debt.

At the same time, the implementation of proposals developed by the authors on the basis of theoretical research and the established practice of introducing digital technologies will make it possible to fully realize the potential of digital transformation of the management resources of tax authorities within the framework of creating a comfortable tax environment. Despite the presence of certain difficulties and risks, the introduction of modern digital technologies in tax administration significantly increases its quality and efficiency, including making the process of paying taxes understandable and convenient for taxpayers [20].

\section{Conclusion}

The introduction of modern digital technologies allows tax authorities to simultaneously improve all areas of their activities: to increase the efficiency of tax control, the quality of interaction with taxpayers, as well as other ministries and departments, to develop international cooperation, etc.

The digital transformation of the management resources of the tax authorities in the future can lead to an improvement in the quality of budget planning, the stability of obligatory payments to the budget system, despite the influence of external factors, as well as an increase in the transparency of the economy and the formation of a comfortable tax environment [21].

The accelerated pace of development of the digital economy has largely influenced the transformation of the management resources of the tax authorities. Today, it is no longer just the development and implementation of modern digital technologies, it is also the renewal of infrastructure, organizational changes, rethinking of the existing approaches to tax control and interaction with taxpayers [22].

At the same time, in order to create an adaptive digital platform, tax authorities need to give priority to not only the introduction of new mechanisms (information systems, digital services, etc.) that will significantly simplify the process of tax administration (make it more transparent and invisible to the taxpayer, reduce tax risks, etc.), improve the efficiency of interaction between tax authorities and taxpayers. It is also necessary to improve on an ongoing basis (refine) existing solutions that have demonstrated their effectiveness, including tax monitoring systems, a special tax regime for the self-employed, the STP system, etc.

So, when studying the impact of digitalization of the economy on the transformation of management resources within the framework of creating a comfortable tax environment, it is necessary to apply an integrated approach, taking into account the changes covering all activities of tax authorities.

\section{References}

1. S. Huseynli, J Curr Debates Soc Sci, 4, 33-47 (2021). https://doi.org/10.37154/cudes.2021.30 
2. A. Mustafa, Digital service taxes as the fiscal result of digital transformation. In U. Hacioglu, T. Aksoy (eds), Financial ecosystem and strategy in the digital era. 355-378. (Springer, Istanbul, Turkey, 2021). https://doi.org/10.1007/978-3-030-72624-9_15

3. T.V. Muravleva, D.D. Orlovskaya, Sci Soc, 3(35), 31-34 (2019)

4. L.N. Galieva, Organization of work with taxpayers in the context of digital transformation of the economy, in Improving tax administration, Materials of the fourth scientific and practical conference, December 06, Ufa (2019)

5. T.Yu. Solodimova, E.G. Grineva, Econ Manag: Curr Trends, 5, 154-157 (2019). https://doi.org/10.31483/r-33410

6. T. Krieger, Int J Innov Tech Econ, 2(34), 1-12 (2021). https://doi.org/10.31435/rsglobal_ijite/30062021/7543

7. D. Bentley, eJournal of Tax Research, 18(2), 353-381 (2020)

8. M. Kačaljak, Bratislava Law Rev, 4, 21-30 (2020). https://doi.org/10.46282/blr.2020.4.2.209

9. OECD. Tax Administration 3.0: The digital transformation of tax administration. Paris, France: OECD Publishing (2020). Accessed on: September 24, 2021. [Online]. Available:

https://www.oecd.org/tax/forum-on-tax-administration/publications-and-products/tax-a dministration-3-0-the-digital-transformation-of-tax-administration.pdf

10. 209 companies will participate in tax monitoring from 2021 (2020). Retrieved from https://www.nalog.gov.ru/rn77/news/activities_fts/10222192/

11. Two million self-employed registered in Russia. (2021). Accessed on: September 24, 2021. [Online]. Available:

https://www.nalog.gov.ru/rn77/news/activities_fts/10747467/

12. I. Zubkov, R. Markelov, Edinyi nalogovyi platezh rasprostranyat na biznes [A single tax payment will be extended to businesses] (2021). Accessed on: September 24, 2021. [Online]. Available:

https://rg.ru/2021/04/01/edinyj-nalogovyj-platezh-rasprostraniat-na-iurlic-i-ip.html

13. C. Williams, E-tax: electronic tax filing (Regional Cooperation Council, Sarajevo, 2021)

14. Tax analytics (2021). Accessed on: September 24, 2021. [Online]. Available: https://analytic.nalog.ru/portal/index.ru-RU.htm

15. P. Bechko, N. Lysa, V. Bechko, S. Ptashnik, Col Works Uman National Univ Horticulture, 2, 143-153 (2021). https://doi.org/10.31395/2415-8240-2021-98-2-143-153

16. S.L. Moiseenko, N.P. Malysheva, Vestnik Altai Acad Econ Law, 3, 194-200 (2021). https://doi.org/10.17513/vaael.1630

17. E.A. Kirova, A.V. Kozhebatkina, Vestnik Univ, 9, 94-99 (2020). https://doi.org/10.26425/1816-4277-2020-9-94-99

18. Unified register of small and medium-sized businesses (2021). Accessed on: September 24, 2021. [Online]. Available: https://rmsp.nalog.ru/

19. Report of the National Research University Higher School of Economics "The market of services for self-employed citizens" (2021). Accessed on: September 24, 2021. [Online]. Available: https://www.hse.ru/mirror/pubs/share/442787036.pdf 
20. B. Firmansah, N. Rahayu, J Manaj Pelayanan Pub, 4, 51-69 (2020). https://doi.org/10.24198/jmpp.v4i1.28005

21. N. Respati, Scientax, 1(2), 109-130 (2020). https://doi.org/10.52869/st.v1i2.38

22. K. Cipek, I. Ljutić, Oditor, 7(1), 37-69 (2021). https://doi.org/10.5937/oditor2101037c 